Invited Lead Lecture. In Proceedings of the International Conference on Soil Water and Environmental Quality: Issues and Strategies, New Delhi, India, 2005, Indian Society of Soil Science, New Delhi, pp. 239-263.

3. Sanyal, S. K, Jeevan Rao, K. and Sadana, U. S., Toxic elements and other pollutants - a threat to nutritional quality. In Soil Science in Service of Nation (eds Goswami, N. et al.), Indian Society of Soil Science, New Delhi, 2012, pp. 266-291.

4. Sanyal, S. K., Gupta, S. K., Kukal, S. S. and Jeevan Rao, K., Soil degradation, pollution and amelioration. In State of Indian Agriculture - Soil (eds Pathak, H., Sanyal, S. K. and Takkar, P. N.), National Academy of Agricultural Sciences (India), New Delhi, 2015, pp. 234-266.

5. Das, I., Ghosh, K., Das, D. K. and Sanyal, S. K., Transport of arsenic in some affected soils of Indian sub-tropics. Soil Res., 2014, 52, 822-832.

6. Ashjaei, S., Miller, W. P., Cabrera, M. L. and Hassan, S. M., Arsenic in soils and forages from poultry litter - amended pastures. Int. J. Environ. Res. Public Health, 2011, 8, 1534-1546.

7. Girouard, E. and Zagury, G. J., Arsenic bioaccessibility in CCAcontaminated soils: influence of soil properties arsenic fractionation and particle-size fraction. Sci. Total Environ., 2009, 407, 2576-2585.

8. Huang, R. Q., Gao, S. F., Wang, W. L., Staunton, S. and Wangm, G., Soil arsenic availability and the transfer of soil arsenic to crops in suburban areas in Fujian province southeast China Sci. Total Environ., 2006, 368, 531-541.

9. Asagba, E. U., Okieimen, F. E. and Osokpor, J., Screening and speciation of heavy metal contaminated soil from an automobile spare-part market. Chem. Spec. Biol., 2007, 19, 9-15.

10. Vacha, R., Macurova, H., Sakala, J. and Cechmankova, J., Evaluation of methods for determination of selected arsenic forms in soils. Pedologist, 2011, 302-313.

11. Wenzel, W. W., Kirchbaumer, N., Prohaska, T., Stingeder, G., Lombi, E. and Adriano, D. C., Arsenic fractionation in soils using an improved sequential extraction procedure. Anal. Chim. Acta, 2001, 436, 309-323.

12. Chang, S. C. and Jackson, M. L., Fractionation of soil phosphorus. Soil Sci., 1957, 84, 133-144.

13. Johnston, S. E. and Barnard, W. M., Comparative effectiveness of fourteen solutions for extracting arsenic from Western New York soils. Soil Sci. Soc. Am. J., 1979, 43, 304-308.

14. McLaren, R. G., Naidu, R., Smith, J. and Tiller, K. G., Fractionation and distribution of arsenic in soils contaminated by cattle dip. J. Environ. Qual., 1998, 27, 348-354.

15. Das, I., Ghosh, K., Das, D. K. and Sanyal, S. K., Studies on fractionation of arsenic in soil in relation to crop Uptake. Soil Sed. Contam., 2011, 20, 790-809.

16. Page, A. L., Miller, R. H. and Keeney, D. R., Methods of Soil Analysis, Part 2: Chemical and Microbiological Properties, ASA and SSSA, Madison, Wisconsin, 2nd edn, 1982.

17. Sparks, D. L. et al., Methods of Soil Analysis. Part 3. Chemical Methods (ed. Sparks, D. L.), Soil Science Society of America, Inc., American Society of Agronomy, Inc.: Madison, Wisconsin, 1996.

ACKNOWLEDGEMENTS. We gratefully acknowledge the financial support received from the Ministry of Water Resources, Government of India (Grant No. 23/28/2002-R\&D/800-814) to conduct the present investigation in the Department of Agricultural Chemistry and Soil Science, Bidhan Chandra Krishi Viswavidyalaya, Nadia, West Bengal, India.

Received 2 February 2016; revised accepted 10 June 2016

doi: $10.18520 / \mathrm{cs} / \mathrm{v} 111 / \mathrm{i} 8 / 1371-1377$

\section{Synthesis of nano-porous carbon from cellulosic waste and its application in water disinfection}

\author{
A. Carmalin Sophia ${ }^{1, *}$, Harjeet Nath $^{2}$ and \\ N. V. S. Praneeth ${ }^{3}$ \\ ${ }^{1}$ CSIR-National Environmental Engineering Research Institute, \\ Taramani, Chennai 600 113, India \\ ${ }^{2}$ Tripura University (A Central University), Suryamaninagar, \\ Agartala 799 022, India \\ ${ }^{3}$ National Institute of Technology, Rourkela 769008 , India
}

The present study deals with the preparation of new cellulosic catalyst materials, viz. paper and textile industry waste. Activated nano-carbons were prepared from these waste materials using thermo-chemical method. Nano-silver particles (AgNP) were embedded into the synthesized carbons to incorporate antimicrobial properties. The catalyst materials were characterized using FESEM-EDX, XRD, FTIR, etc. The characterization results showed that the materials were nanoporous and silver was uniformly distributed throughout the catalyst. The suitability of the catalyst as an antimicrobial agent was studied using pour plate technique. The main advantages of the disinfecting materials over conventional materials were: (i) only small quantities (mg) of catalysts are required to deactivate microorganism for up to 1 litre of water; (ii) time required for more than $99 \%$ disinfection is less (60 min); (iii) carbon has been synthesized from cellulosic wastes which otherwise would pollute the environment, hence it is a waste recycling process. The carbons exhibited more than $99 \%$ E. coli removal within $60 \mathrm{~min}$.

Keywords: Cellulosic waste recycling, disinfection, $E$. coli, nano-carbon, nano-silver.

SAFETY of drinking water is taken for granted in most developing countries. Water pollution caused by faecal contamination is a serious problem. E. coli contaminated waters when used as drinking water, cause severe diarrhoea, abdominal cramps and in some cases may cause severe anaemia or kidney failure. Approximately 12 million people die yearly due to water-borne diseases. Most diseases occurring in developing countries are due to consumption of contaminated water ${ }^{1-3}$. In the past few decades, clean-water received much attention ${ }^{4,5}$. Water is disinfected through different techniques such as chlorination, UV treatment, ozonization, etc. However, these disinfection routes have limitations due to their cost and difficulties in large scale implementation ${ }^{6-9}$.

Water purification using nanotechnology utilizes nanoscopic materials such as nano-carbon, carbon nanotubes,

*For correspondence. (e-mail: ac_sophia@neeri.res.in) 
and alumina fibers for nanofiltration. Nanomaterial applications open the door for removal of pathogens from water due to their highly reactive surface that kill the microorganisms. Several researchers have studied disinfection and purification of water using nanomaterials ${ }^{10-15}$. Many such nanomaterials (single and multiwalled nanotubes, those that use nano-gold) are not economical ${ }^{10,12,14}$. These materials also have handling difficulties. Hence, the challenge is to develop scientific, yet economically feasible materials for water disinfection which could be affordable to all sections of the society.

The present study reports the synthesis of two new activated carbons from cellulosic industrial waste sources. This study is novel as these carbons are developed from waste materials and have not been used elsewhere for water purification. Nano-Ag has been incorporated into these carbons and utilized as an antimicrobial agent $(\mathrm{AgNP})^{16}$. These nanoparticles are effective owing to high surface area and their ability to pass through the cell membrane disrupting cell mechanism by damaging the DNA of the microorganism ${ }^{16}$ leading to cell death.

The materials used for this work are used/recycled paper and textile manufacturing industry waste. Textile waste comprises waste material obtained from textile finishing. This material is rigid, and non-biodegradable. This waste accumulated in textile industries for many years has no effective use and is indiscriminately disposed of in land or burnt. E. coli culture was obtained from IMTECH, Chandigarh.

The paper and textile waste was washed several times to remove the dirt and dust and later sun-dried. The dry sample was thermochemically activated using $1 \% \mathrm{H}_{2} \mathrm{SO}_{4}$ at $300^{\circ} \mathrm{C}$. Silver nanoparticles were prepared from $0.001 \mathrm{M} \mathrm{AgNO}_{3}$ using a reducing agent $\mathrm{NaBH}_{4}$ (ref. 17). Carbon sample $(1 \mathrm{~g})$ was loaded with $60 \mu \mathrm{g}$ of $\mathrm{nAg}$ in solution, stirred for $1 \mathrm{~h}$ followed by evaporation on a hot plate for $5 \mathrm{~h}$. The dried samples were then reduced in a flow of hydrogen at $250^{\circ} \mathrm{C}$ for $3 \mathrm{~h}$ washed with deionized water and dried again and stored for disinfection experiments.

After using the materials for the first run of disinfection, they were filtered, washed in deionized water and dried in hot air oven for $4 \mathrm{~h}$ at $100^{\circ} \mathrm{C}$ and used for the next batch. The material was reused $n$ number of times until the disinfection performance reduced to less than $90 \%$ in $60 \mathrm{~min}$.

The $\mathrm{pH}$, moisture content and bulk density of the adsorbents were determined according to standard methods ${ }^{18}$. The characteristics of the adsorbent materials used in this study are given in Table 1.

The Brunauer-Emmett-Teller (BET) specific surface area of carbon samples was determined using ASAP 2010 automatic physical adsorber and highly purified nitrogen gas. The surface area exhibited by the samples is shown in Table 2. The paper waste-based catalysts (PWACT and PWAGNP) exhibited a surface area higher than textile waste-based sample (TWACT and TWAGNP) perhaps due to differences in their cellulose unit cell structure. Similar surface area values have been obtained earlier ${ }^{19}$ for nano-silver-carbon covered alumina catalyst prepared by electro-chemical method for drinking water purification. The surface area provided adequate sites for the silver nano-particle adsorption. All the carbons from industrial wastes were nanoporous thus giving better support in effectively controlling the microorganisms in water.

XRD was analysed on all the four samples synthesized using Philips X'Pert X-ray diffractometer. The XRD patterns of various carbon samples are shown in Figure 1. The peaks show that the majority of phases consisted of $\mathrm{CaSO}_{4}, \mathrm{CaCl}_{2}, \mathrm{CaCO}_{3}, \mathrm{SiO}_{2}, \mathrm{Na}_{2} \mathrm{~S}$ and $\mathrm{Na}_{2} \mathrm{O}$. The samples are basically cellulosic and their major phase composition was observed to be almost the same. $\mathrm{Ag}_{2} \mathrm{O}$ peaks appear in the silver incorporated samples. X-ray line broadening (XLB) shows particle size of silver in PWAGNP and TWAGNP. PWAGNP has the silver with average particle size approximately $20-25 \mathrm{~nm}$ and TWAGNP has the silver with average particle size approximately $25-27 \mathrm{~nm}$. Average particle size of nanosilver in the catalysts was further confirmed from the FESEM results. Similar silver nanoparticles of size 25-27 nm have been reported by Sashikala et al. ${ }^{19}$.

Fourier transform-infrared (FT-IR) spectroscopy was carried out using Perkin Elmer and Bruker Vector 22 FTIR instrument. The FT-IR spectra of various nano-carbon samples synthesized are presented in Figure 2. The FT-IR peaks suggest that the materials synthesized are carbonaceous with a large number of active functional groups namely, hydroxyl, carbonyl or carboxylic acid. The carbon samples exhibit characteristic absorption bands of $\mathrm{O}-\mathrm{H}$ stretching vibrations in the range $3435-3600 \mathrm{~cm}^{-1}$. This strong broad band attributes to the presence of adsorbed water by carbon samples. The sharp band between 1300 and $1400 \mathrm{~cm}^{-1}$ can be assigned to bending in-plane $-\mathrm{OH}$ vibrations or to bending in plane symmetry. $\mathrm{C}-\mathrm{H}$

Table 1. Characterization of carbons

\begin{tabular}{lcccc}
\hline Parameter & PWACT & PWAGNP & TWACT & TWAGNP \\
\hline $\mathrm{pH}(1 \%$ slurry $)$ & 5.85 & 5.59 & 6.05 & 5.91 \\
Surface area $\left(\mathrm{m}^{2} / \mathrm{g}\right)$ & 347.146 & 345.225 & 283.438 & 275.228 \\
Bulk density $(\mathrm{g} / \mathrm{ml})$ & 0.45 & 0.48 & 0.40 & 0.41 \\
Moisture content $(\%)$ & 4.10 & 4.60 & 4.76 & 5.02 \\
\hline
\end{tabular}

Table 2. Surface area of catalysts

\begin{tabular}{lc}
\hline Sample & Surface area $\left(\mathrm{m}^{2} / \mathrm{g}\right)$ \\
\hline PWACT & 347.146 \\
PWAGNP & 345.225 \\
TWACT & 283.438 \\
TWAGNP & 275.228 \\
\hline
\end{tabular}


stretching vibrations are observed between 2800 and $2900 \mathrm{~cm}^{-1}$. The stretching vibrations between 1500 and $1700 \mathrm{~cm}^{-1}$, correspond to $\mathrm{C}=\mathrm{O}$ (ref. 5). The peaks obtained in the range $1080-1090 \mathrm{~cm}^{-1}$ indicate the presence of $\mathrm{Si}-\mathrm{O}-\mathrm{Si}$ bonds ${ }^{20}$. Earlier we have reported similar stretching and bending vibrations ${ }^{21}$.

Anti-bacterial activity of the synthesized nano-carbon materials was tested by stirring $1 \mathrm{mg}$ of PWACT, TWACT, PWAGNP and TWAGNP in $1000 \mathrm{ml}$ of water spiked with $E$. coli in a $2000 \mathrm{ml}$ sterile, transparent glass vessel with screw cap for 10-30 min (200 RPM) in a batch mode at ambient conditions. Later, the catalyst was filtered off and the water was tested for E. coli count. The antibacterial activity was estimated by pour plate method previously explained ${ }^{21}$. Distilled water with no catalyst was used as a blank. Table 3 and Figure 3 show the antibacterial activity results for various carbon samples. Figure 4 schematically explains the mechanism.

It is observed that more than $99 \%$ of the bacteria were killed within $30 \mathrm{~min}$. The influent $\mathrm{pH}$ was found to be 7.72 while the outlet $\mathrm{pH}$ varied from 6.39 to 6.65 after

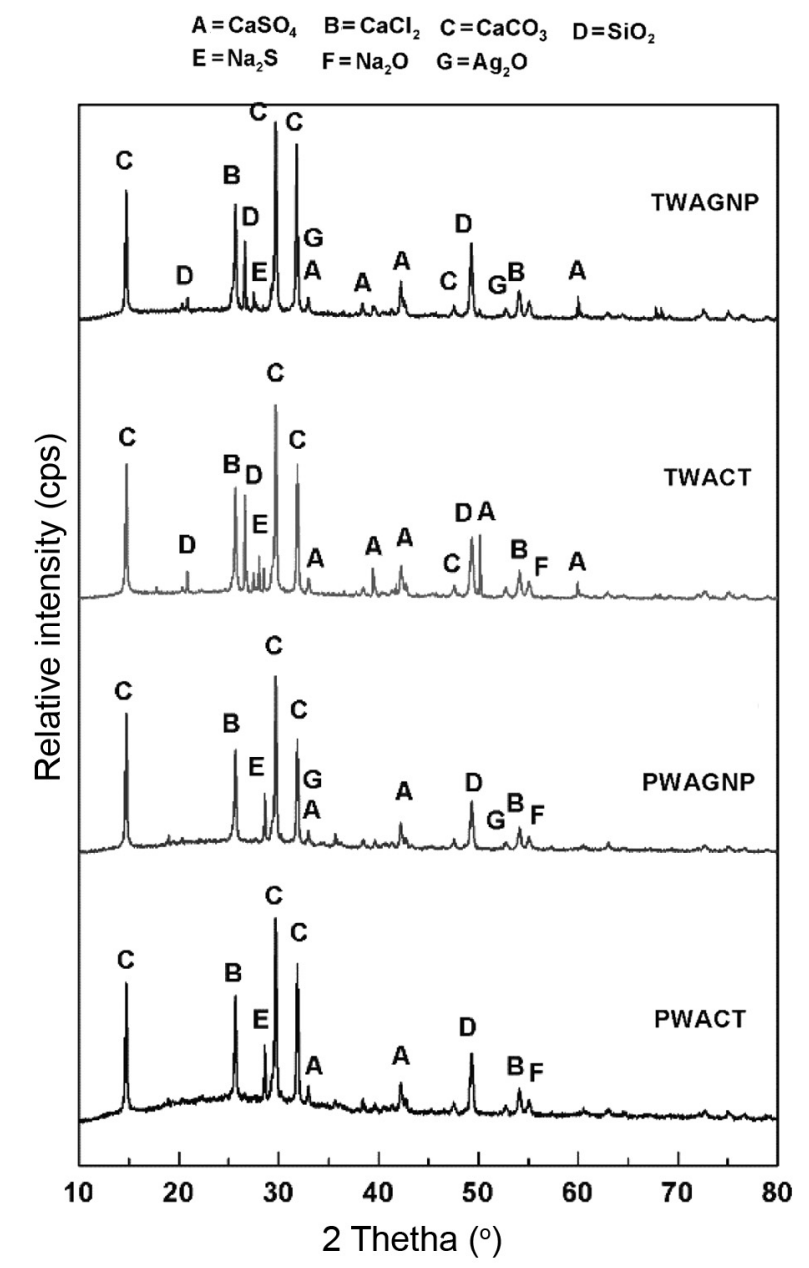

Figure 1. XRD patterns of the carbon-catalyst samples. the batch mode experiments. It was found that the nanoAg impregnated nano-carbon obtained from paper showed $99.6 \%$ disinfection after $10 \mathrm{~min}$ of batch mode stirring. All the catalysts studied could remove E. coli $>99 \%$ at the end of $60 \mathrm{~min}$. The higher anti-microbial activity exhibited by $\mathrm{Ag}$ incorporated nano-carbons due to several reasons had been explained earlier ${ }^{20,22-31}$. The material was reused six times until the disinfection performance reduced to less than $90 \%$ in $60 \mathrm{~min}$.

Silver aided deactivation of disease-causing organisms had been discussed earlier ${ }^{19,22,25}$. There are various assumptions on how silver nanoparticles act on microbes to cause the microbicidal effect. Few of them are listed below:

- Silver nanoparticles have the ability to cling onto the bacterial cell wall and subsequently penetrate it, thereby causing damage to the cell wall and ultimately death of the cell.

- There can be formation of 'holes' on the cell wall, on the sites of accumulation of nanoparticles ${ }^{23}$.

- The formation of free radicals by silver nanoparticles may be considered to be another mechanism by which the cells die. There are studies that suggest formation

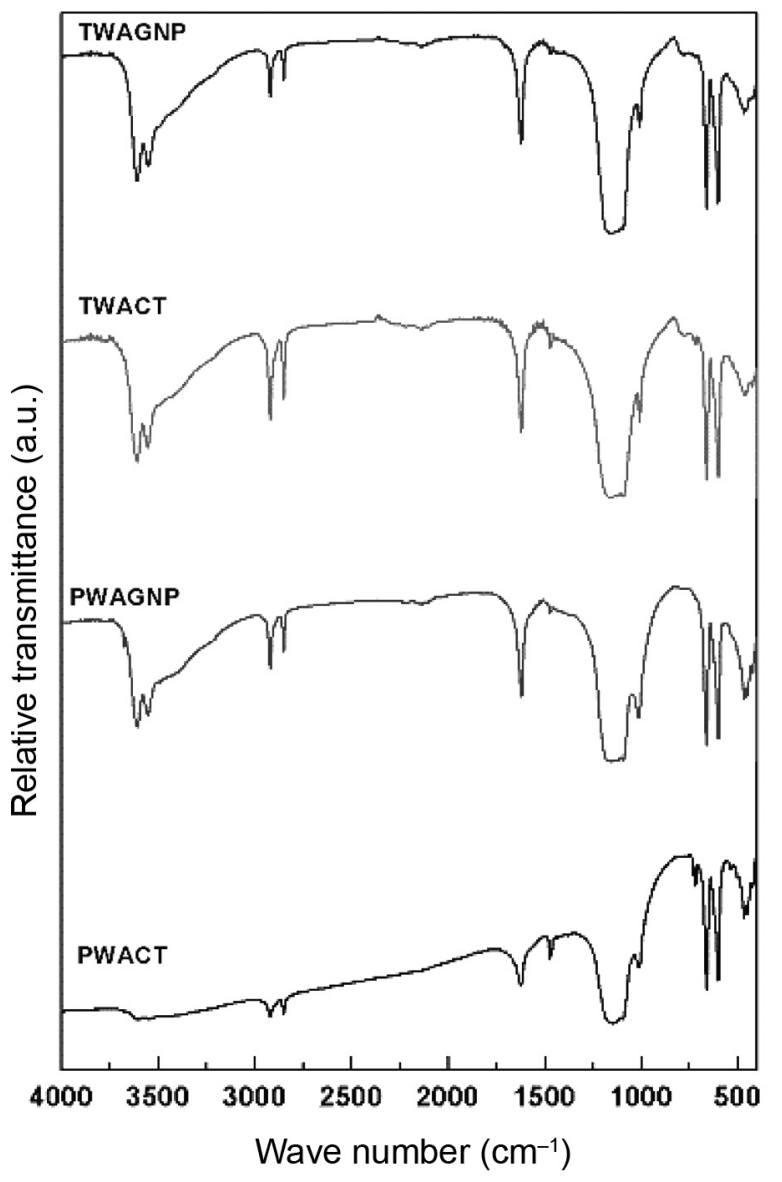

Figure 2. FT-IR spectrum of the carbon-catalyst samples. 
Table 3. Anti-bacterial activity of the various catalyst-carbon samples

\begin{tabular}{lcccccc}
\hline & \multicolumn{5}{c}{ Average removal (\%) } \\
\cline { 2 - 7 } Sample & $10 \mathrm{~min}$ & Average $\mathrm{pH}$ & $20 \mathrm{~min}$ & Average $\mathrm{pH}$ & $60 \mathrm{~min}$ & Average $\mathrm{pH}$ \\
\hline PWACT & $95.0 \pm 1.1 \%$ & 6.54 & $98.0 \pm 0.9 \%$ & 6.41 & $99.9 \pm 0.05 \%$ & 6.39 \\
PWAGNP & $99.6 \pm 0.3 \%$ & 6.48 & $99.9 \pm 0.06 \%$ & 6.43 & $99.9 \pm 0.04 \%$ & 6.43 \\
TWACT & $86.6 \pm 1.4 \%$ & 6.62 & $90.2 \pm 1.4 \%$ & 6.56 & $99.9 \pm 0.06 \%$ & 6.54 \\
TWAGNP & $90.3 \pm 1.3 \%$ & 6.65 & $95.3 \pm 1.2 \%$ & 6.51 & $99.9 \pm 0.05 \%$ & 6.46 \\
\hline
\end{tabular}

Initial E. coli conc.: $5 \times 10^{3} \mathrm{cfu} / \mathrm{ml}$; influent $\mathrm{pH}: 7.72$.
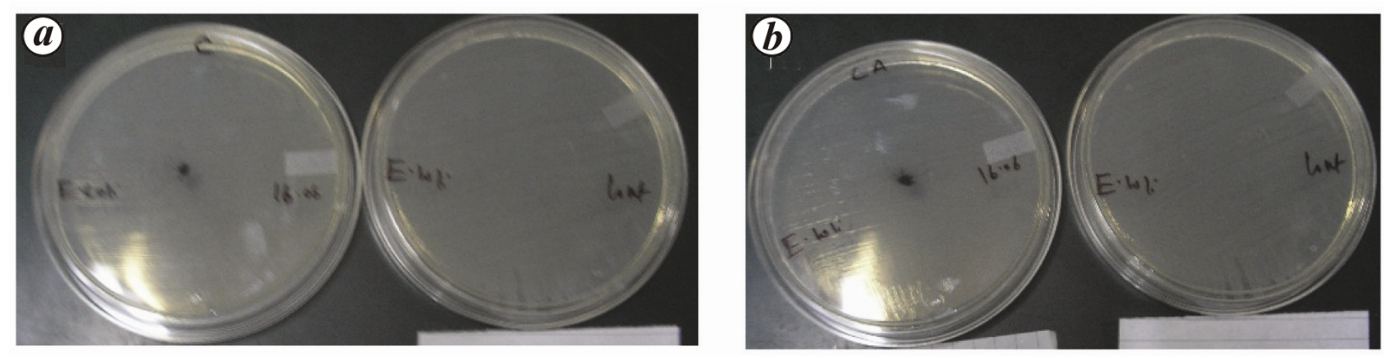

Figure 3. Petri dishes with NB-agar inoculated with E. coli in presence of $1 \mathrm{mg}$ of (a) PWAGNP and (b) TWAGNP.

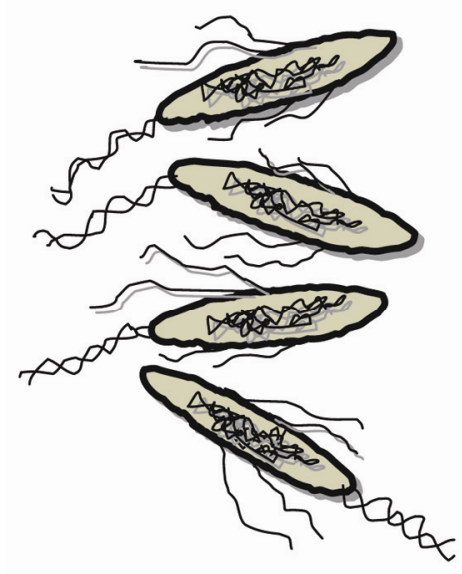

E. coli

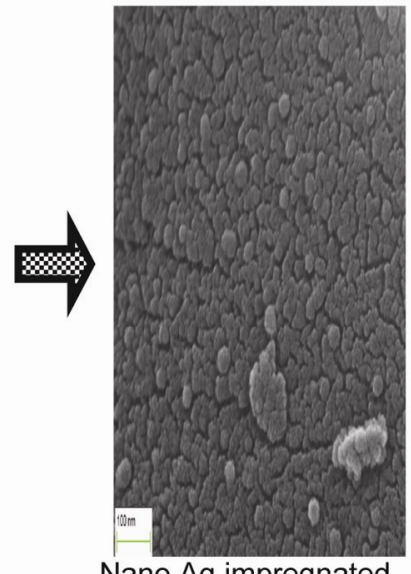

Nano Ag impregnated activated carbon from waste materials

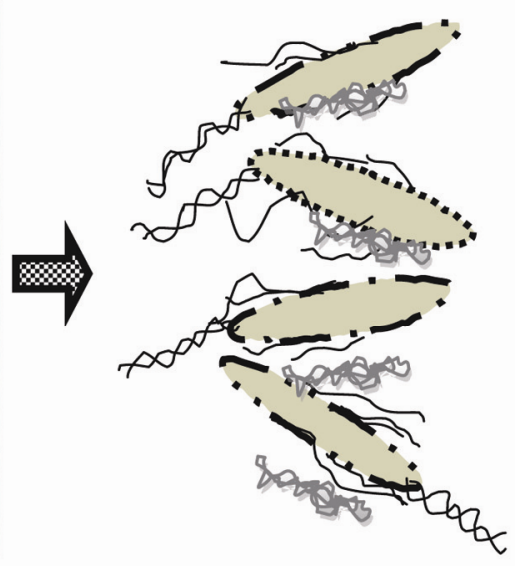

Dead E. coli

Figure 4. Disinfection mechanism.

of free radicals by silver nanoparticles when in contact with the bacteria, and these free radicals can damage the cell membrane ultimately leading to cell death $^{24,25}$.

- Nano-silver ions can interact with thiol groups of many vital enzymes and inactivate them ${ }^{26,27}$.

- Metals such as $\mathrm{Au}, \mathrm{Ag}$ and $\mathrm{Cu}$ have affinity towards oxygen. It is reported that atomic oxygen perfectly fits into the octahedral holes of these metals.

- Silver has a tendency to bind to nascent oxygen (binding energy $=40 \mathrm{kcal} / \mathrm{mol}$ ) and it readily oxidizes bacteria or viruses, resulting in complete disintegration ${ }^{19}$.

- Silver is a soft acid and the cells are mostly made up of sulphur and phosphorus which are soft bases. The action of these nanoparticles on the cell can cause the reaction subsequently leading to cell death. DNA has sulphur and phosphorus as its major components; the nanoparticles can act on these soft bases and destroy DNA which turns detrimental to the cells ${ }^{28}$.

- The interaction of silver nanoparticles with sulphur and phosphorus of the DNA can lead to problems in DNA replication of the bacteria and thus terminate the microbes.

Thus, nano-Ag on activated carbon seems to be more advantageous particularly in reusing the catalyst.

FESEM-EDX analysis was performed using Nova Nano SEM 450 and the results are presented in Figure 5. 

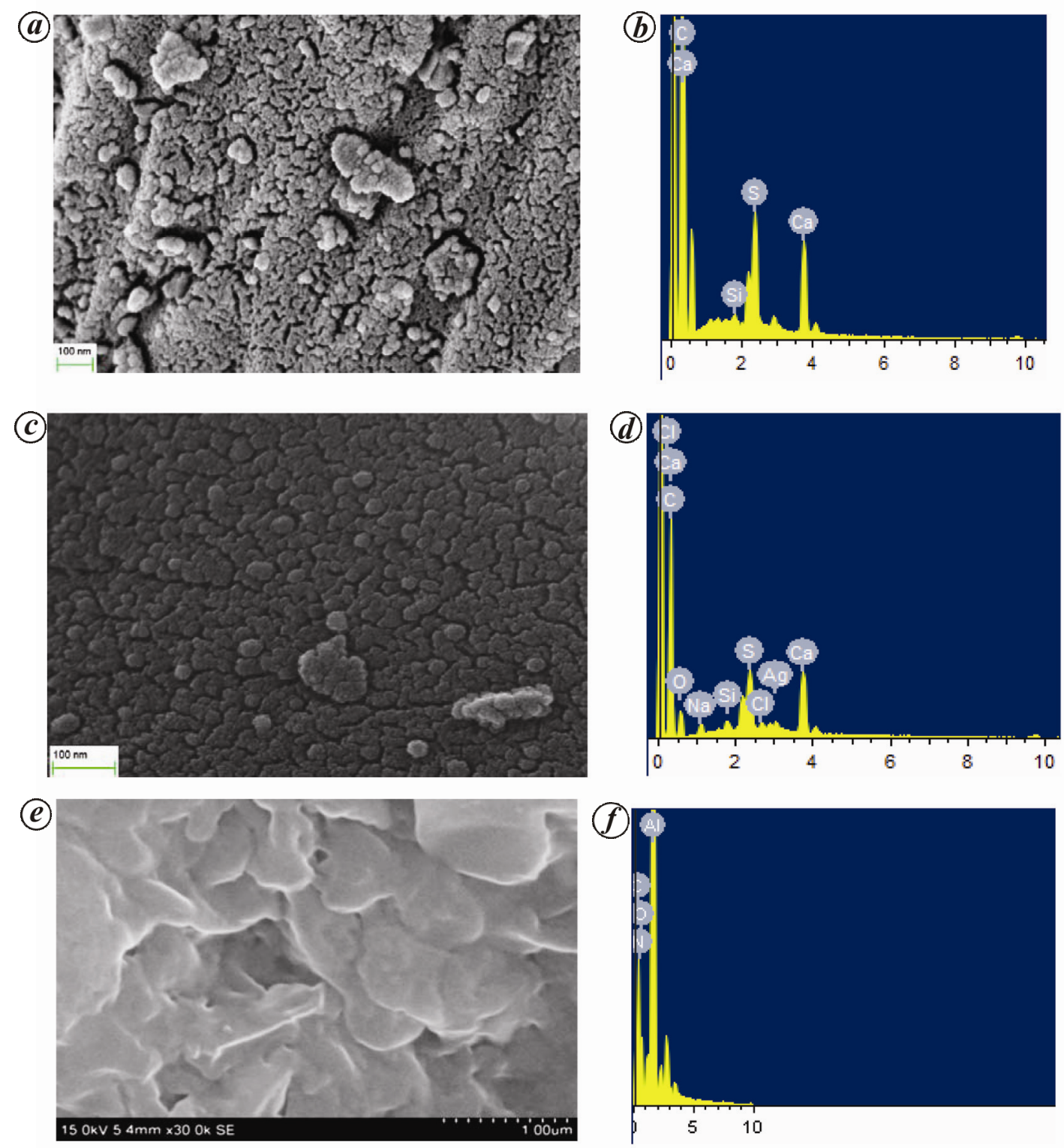

Figure $5 \boldsymbol{a}-\boldsymbol{f}$. FESEM and EDX reports of the carbon samples prepared from paper and textile waste. FESEM (a), EDX $(\boldsymbol{b})$ image of PWACT; FESEM $(\boldsymbol{c}), \operatorname{EDX}(\boldsymbol{d})$ image of PWAGNP; FESEM $(\boldsymbol{e}), \operatorname{EDX}(\boldsymbol{f})$ image of TWACT.

TWACT, PWACT and PWAGNP were chosen for FESEM analysis as they showed the highest antibacterial activity. It can be seen from Figure 5 that all the samples analysed (TWACT, PWACT, PWAGNP) were observed to be nanoporous. The carbon nanoparticles are uniformly distributed in the samples. The textile waste sample had a rather flaky appearance different from the paper waste sample. Silver particles are clearly seen in PWAGNP sample prepared. The EDX and XRD analysis further confirms the same. EDX also shows presence of $\mathrm{C}, \mathrm{Ca}$, $\mathrm{Si}$, etc. Similar SEM images have been reported for activated carbon granules coated with silver nanoparti$\operatorname{cles}^{29,30}$. There are other studies that have reported presence of flower-like silver nanoparticles for silver incorporated on multi-walled carbon nanotube $\mathrm{e}^{31,32}$.
Different types of activated carbons have been developed from natural sources ${ }^{33}$, but this study has developed two new nano-catalysts from waste materials. These materials investigated for the first time for production of nano-carbon are used in water disinfection. The present study indicates that these catalysts possess high potential for removal of $E$. coli. The impregnation of nano-Ag in carbons increased the bactericidal properties of the materials. The materials were found to have a high surface area $\left(283-347 \mathrm{~m}^{2} / \mathrm{g}\right)$. FE-SEM results show that carbons synthesized are nanoporous. EDX results prove the incorporation of nano Ag onto the carbon material. FTIR characterization of the carbons shows the presence of $\mathrm{C}=\mathrm{O}$ and $-\mathrm{OH}$ in the carbons which may be responsible for the adsorption. The main advantages and innovation 
in this research study are the catalysts: (i) the method of preparation is highly economical; (ii) these Ag supported catalysts are reusable; (iii) $1 \mathrm{mg}$ is enough to treat 1 litre of $E$. coli contaminated sample and (iv) $99 \%$ disinfection can be obtained within $60 \mathrm{~min}$ in batch mode.

1. Malik, A., Yasar, A., Tabinda, A. B. and Abubakar, M., Waterborne diseases, cost of illness and willingness to pay for diseases interventions in rural communities of developing countries. Iran. J. Public Health, 2012, 41, 39-49.

2. Ezzati, M., Lopez, A. D., Rodgers, A. and Murray, C. J. L., Comparative quantification of health risks: global and regional burden of disease attributable to selected major risk factors, World Health Organization, 2004, vol. 1.

3. Global health risks: mortality and burden of disease attributable to selected major risks, World Health Organization, 2009.

4. Li, Q., Mahendra, S., Lyon, D. Y., Brunet, L., Liga, M. V., Li, D. and Alvarez, P. J. J., Antimicrobial nanomaterials for water disinfection and microbial control: Potential applications and implications. Water Res., 2008, 42, 4591-4602.

5. Wei, J. et al., Simple one-step synthesis of water-soluble fluorescent carbon dots derived from paper ash. ESIRSC Adv., 2013, 3 , 13119-13122.

6. Kim, B. R., Anderson, J. E., Mueller, S. A., Gaines, W. A. and Kendall, A. M., Literature review-efficacy of various disinfectants against Legionella in water systems. Water Res., 2002, 36, 44334444.

7. Gopal, K., Tripathy, S. S., Bersillon, J. L. and Dubey, S. P., Chlorination byproducts, their toxicodynamics and removal from drinking water. J. Hazard. Mater., 2007, 140, 1-6.

8. Sadiq, R. and Rodriguez, M. J., Disinfection by-products (DBPs) in drinking water and predictive models for their occurrence: a review. Sci. Total Environ., 2004, 312, 21-46.

9. Rodrigues, D. F. and Elimelech, M., Toxic effects of single-walled carbon nanotubes in the development of E. coli biofilm. Environ Sci. Technol., 2010, 44(12), 4583-4589.

10. Akhavan, O., Abdolahad, M., Abdi, Y. and Mohajerzadeh, S., Synthesis of titania/carbon nanotube heterojunction arrays for photo inactivation of $E$. coli in visible light irradiation. Carbon, 2009, 47(14), 3280-3287.

11. Kang, S., Herzberg, M., Rodrigues, D. F. and Elimelech, M., Antibacterial effects of carbon nanotubes: size does matter. Langmuir, 2008, 24(13), 6409-6413.

12. Lingrong, G. et al., Single-walled carbon nanotubes displaying multivalent ligands for capturing pathogens. Chem. Commun., 2005, 21(7), 874-876.

13. Zhang, $\mathrm{H}$. and Chen, G., Potent antibacterial activities of $\mathrm{Ag} / \mathrm{TiO}_{2}$ nanocomposites powders synthesized by a one-pot sol-gel method. Environ. Sci. Technol., 2009, 34, 2905-2910.

14. Sandhya, S., Rayalu, S. and Bruno, B., Solar light induced photo catalytic disinfection of Gram-positive and negative microorganisms from water with highly efficient $\mathrm{AuTiO}_{2}$ nanoparticle. J. Bioproces. Biotechnol., 2014, 4, 6-12.

15. Sharma, V. K., Yngard, R. A. and Lin, Y., Silver nanoparticles: Green synthesis and their antimicrobial activities. Adv. Colloid Interface Sci., 2009, 145, 83-96.

16. Lei, G., Synthesis of nano-silver colloids and their anti-microbial effects, M Sc thesis, Virginia Polytechnic Institute and State University, Blacksburg, Virginia, 2007.

17. Mavani, K. and Shah, M., Synthesis of silver nanoparticles by using sodium borohydride as a reducing agent. Int. J. Eng. Res. Technol., 2013, 2, 1-5.

18. Standard Methods for the Examination of Water and Wastewater, American Public Health Association, Washington DC, 2012, 22nd edn.
19. Shashikala, V., Kumar, V. S., Padmasri, A. H., Raju, B. D., Mohan, S. V., Sarma, P. N. and Rao, K. S. R., Advantages of nanosilver-carbon covered alumina catalyst prepared by electrochemical method for drinking water purification. J. Mol. Catal. A Chem., 2007, 268, 95-100.

20. Li, L., Zhang, H. and Zhuang, X., Pyrolysis of waste paper: characterization and composition of pyrolysis oil. Energ. Sour., 2005, 27, 867-873.

21. Sophia, A. C., Catherine, D. and Bhalambaal, V. M., Utilization of rice-husk and coconut shell carbons for water disinfection. J. Environ. Sci. Eng., 2013, 55, 9-16.

22. Davies, R. L. and Etris, S. F., The development and functions of silver in water purification and disease control. Catal. Today, 1997, 36, 107-114.

23. Sondi, I. and Salopek, B. S., Silver nanoparticles as antimicrobial agent: A case study on E. coli as a model for Gram-negative bacteria. J. Colloid Interface Sci., 2004, 275, 177-182.

24. Danilczuk, M., Lund, A., Sadlo, J., Yamada, H. and Michalik, J., Conduction electron spin resonance of small silver particles. Spectrochim. Acta Mol. Biomol. Spectrosc., 2006, 63, 189-191.

25. Kim, J. S. et al., Antimicrobial effects of silver nanoparticles. $\mathrm{Na}$ nomedicine, 2007, 3, 95-101.

26. Feng, Q. L., Wu, J., Chen, G. Q., Cui, F. Z., Kim, T. N. and Kim, J. O., A mechanistic study of the antibacterial effect of silver ions on Escherichia coli and Staphylococcus aureus. J. Biomed. Mater Res., 2000, 52, 662-668.

27. Matsumura, Y., Yoshikata, K., Kunisaki, S. and Tsuchido, T., Mode of bactericidal action of silver zeolite and its comparison with that of silver nitrate. Appl. Environ. Microbiol., 2003, 69, 4278-4281.

28. Morones, J. R., Elechiguerra, J. L., Camacho, A., Holt, K., Kouri, J. B., Ramírez, J. T. and Yacaman, M. J., The bactericidal effect of silver nanoparticles. Nanotechnology, 2005, 16, 2346-2353.

29. Akhavan, O., Abdolahad, M., Abdi, Y. and Mohajerzadeh, S., Silver nanoparticles within vertically aligned multi-wall carbon nanotubes with open tips for antibacterial purposes. J. Mater. Chem., 2011, 21, 387-393.

30. Hameed, M. A., El-Aassar, Said, M. M., Gawad, A. M. and Shawky, H. A., Using silver nano particles coated on activated carbon granules in columns for microbiological pollutants water disinfection in Abu Rawash area, Great Cairo, Egypt. Aust. J. Basic Appl. Sci., 2013, 7, 422-432.

31. Rananga, L. E. and Magadzu, T., Interaction of silver doped carbon nanotubes-cyclodextrin nanocomposites with Escherichia coli bacteria during water purification. Water Sci. Technol., 2014, 14, 367-375.

32. Rananga, L. E. and Magadzu, T., Comparative studies of silver doped carbon nanotubes and $\beta$-cyclodextrin for water disinfection. Digest, J. Nanomater. Biost., 2015, 10, 831-836.

33. Betzy, N. T. and Soney, G. C., Production of activated carbon from natural sources. Trends Green Chem., 2015, 1, 1-7.

ACKNOWLEDGEMENTS. We thank the Director, CSIR-NEERI for support and permission to carry out this work at CSIR-NEERI's Chennai Zonal Laboratory. Research funding was provided by Clean Water Initiative ESC-00306: project no. CW 2B 3.3.5. We also thank Dr Nitin Labhsetwar for helpful suggestions.

Received 21 September 2015; revised accepted 23 May 2016

doi: $10.18520 / \mathrm{cs} / \mathrm{v} 111 / \mathrm{i} 8 / 1377-1382$ 